\title{
The Economic Effects of Organic Agriculture in Reducing the Emission Greenhouse Gases
}

\author{
Dr. Khaled EI SayedAbd El Mowla Mohamed \\ Senior Researcher-Central Lab. of Organic Agriculture- Agricultural Research Center
}

\section{Introduction}

Agriculture is both a producer and consumer of energy. It uses large quantities of locally available non-commercial energy, such as seed, manure and animate energy, as well as commercial energies, directly and indirectly, in the form of diesel fuel, electricity, fertilizer, plant protection, chemical, irrigation water, machinery etc. Efficient use of these energies helps to achieve increased production and productivity and contributes to the profitability and competitiveness of agriculture sustainability in rural living (Singh et al., 2002). Future agricultural sustainability will be achieved from an equilibrated solution of many productive, environmental, and economic issues (Park and Seaton,1996). Among these, improved energy efficiency and reduced greenhouse gas (GHG) emissions are fundamental (Dyer and Desjardins, 2003; Alluvione et al.,2011). While the energy requirements of agriculture are low compared to other production sectors (Tolet al., 2009), realizing efficient use of its own energy needs is pivotal to achieving economic sustainability and GHG emission reductions (Alluvioneet al., 2011).

Usually, input-output energy analysis is used to evaluate the efficiency and environmental impacts of the production systems. Therefore, there was an immediate need to carry out such analysis for future steps to be taken for any improvement in production systems regarding the energy values of the inputs and the output. By reaching beyond agricultural boundaries and including all the steps of crop input production, energy analysis is a useful indicator of environmental and long-term sustainability (Alluvioneet al., 2011).

Energy use is one of the key indicators for developing more sustainable agricultural practices (Streimikieneet al., 2007) and efficient use of energy is one of the principal requirements of sustainable agriculture (Kizilaslan, 2009). It is important, therefore, to analyze cropping systems in energy terms and to evaluate alternative solutions, especially for arable crops, which account for more than half of the primary sector energy consumption (Sartoriet al., 2005).

\section{Research problem:}

Misuse of agricultural production inputs from fertilizers and chemical pesticides, leading to increased emissions of greenhouse gases.As well as the high cost of applying good practices in agriculture.

\section{Research objective:}

That the application of policies and practices to reduce greenhouse gases in agriculture can be carried out at low or even cost-free costs for farmers in the developing world and, in some cases, can raise their productivity while making them less vulnerable to climate change and thereby provide security World Food. 
The main objective of this study is to examine energy use pattern and specification of GHG emission for organic and traditional tomato production in Egypt.

\section{2-Materials and methods:}

Organic agriculture as an alternative approach to maximize the performance of renewable resources and increase the flow of food and energy in agroecosystems.Life cycle assessments show that emissions from conventional production systems are always higher than organic systems, and the question is whether organic agriculture reduces greenhouse gas emissions from agricultural production. What is the yield of the expansion of cultivated areas with organic farming systems?

This research aims at clarifying the importance of organic agriculture in mitigating the effects of greenhouse gases through a comparative study of tomato yield in organic and traditional farming systems in Egypt, as well as the study of energy use patterns and the analysis of inputs and outputs for organic and traditional tomato production.

A survey was carried in 2017 by interviewing 30 Farmers in Ismailia governorate. The greenhouses were selected for energy analysis and efficiency of tomato. The selection of Farmers was based on random sampling method. In the village of Sarbiom, Abo Sultan and ElQantra Shark.

Firstly, the amounts of inputs such as (pesticides, human power, machinery, total chemical fertilizers and manure, diesel fuel, seed and irrigation water) used in production of tomato were specified in order to calculate the energy equivalences in the study. The values in (Table 1) were used to find the input amounts. The amounts of the inputs were calculated per Feddanand then, these inputs data were multiplied by the coefficient of energy equivalent. Previous studies were used to determine the energy equivalents coefficients. These sources are given in (Table 1).

The energy equivalences of unit inputs are given in mega joule (MJ) per unit. The total input equivalent can calculate by adding up the energy equivalences of all inputs. Based on the energy equivalents of the inputs and output (Table 1), the energy ratio (energy use efficiency), energy productivity, specific energy and net energy gain were calculated (Singh et al., 2002):

Diesel energy requirement was determined on the basis of fuel consumption, $\mathrm{L}$ $/ \mathrm{h}$. The data were converted into energy units and expressed in $\mathrm{MJ} / \mathrm{fed}$. The following equation was used in the calculation of fuel consumption (Canakci M 2005):

$\mathrm{FC}=P_{m} \times R \times S F C$

Where $\mathrm{FC}$ is the fuel consumption, $\mathrm{L} / \mathrm{fed} ; \mathrm{P}_{\mathrm{m}}$ is the tractor power, $\mathrm{kW} ; \mathrm{R}$ is the loading ratio, decimal; and SFC is the specific fuel consumption $(0.300 \mathrm{~L} \mathrm{~kW} / \mathrm{h})$.

In this study the fuel requirements of water pumps (stationary type) and combine harvesters were measured by the following method: the fuel tank of the engine was completely filled before starting the field test, and the quantity of fuel required to fill the tank after performing the field test was measured using a one $\mathrm{L}$ graduated cylinder. Thus, the fuel consumed during the test was determined (Canakci M 2005). 
Based on the energy equivalents of the inputs and output (Table 1), the energy ratio (energy use efficiency), energy productivity, specific energy and net energy gain were calculated (Mohammadi A 2010)

$$
\begin{aligned}
& \text { Energy ratio (Energy use efficiency) }=\frac{\text { Energy Output (MJ/fed) }}{\text { Energy Input (MJ/fed) }} \\
& \text { Energy productivity }=\frac{\text { Yield (kg / fed) }}{\text { Energy Input (MJ/fed) }} \\
& \text { Specific Energy }=\frac{\text { Energy Input (MJ/fed) }}{\text { Yield }(\mathrm{kg} / \mathrm{fed})}
\end{aligned}
$$

Net energy = Energy Output $(\mathrm{MJ} /$ fed $)$ - Energy Input $(\mathrm{MJ} / \mathrm{fed})$

Table :1 Energy equivalents for different inputs and outputs in agricultural production

\begin{tabular}{|c|c|c|c|}
\hline Energy source & Units & MJ* & References \\
\hline 1. Human power & - & & \\
\hline Man & $\mathrm{h}$ & 1.96 & De D, Singh 2001 \\
\hline Woman & $\mathrm{h}$ & 1.57 & De D, Singh 2001 \\
\hline 2. Chemical fertilizer & - & - & \\
\hline $\mathrm{N}$ & $\mathrm{kg}$ & 66.14 & De D, Singh 2001 \\
\hline $\mathrm{P}_{2} \mathrm{O}_{5}$ & $\mathrm{~kg}$ & 12.44 & De D, Singh 2001 \\
\hline $\mathrm{K}_{2} \mathrm{O}$ & $\mathrm{kg}$ & 11.15 & De D, Singh 2001 \\
\hline 3. Diesel fuel & $\mathrm{L}$ & 47.8 & Hetz EJ. 1998 \\
\hline 4. Tractor & $\mathrm{h}$ & 93.61 & Hetz EJ. 1998 \\
\hline 5. Agricultural machinery & $\mathrm{h}$ & 62.7 & Hetz EJ. 1998 \\
\hline 6. Combine & $\mathrm{h}$ & 87.63 & Hetz EJ. 1998 \\
\hline 7. Chemical poison & $\mathrm{kg}$ & - & \\
\hline Herbicides & $\mathrm{kg}$ & 238 & Singh JM. 2002 \\
\hline Fungicies & $\mathrm{kg}$ & 216 & Singh JM. 2002 \\
\hline Insecticides & $\mathrm{kg}$ & 101.2 & Singh JM. 2002 \\
\hline 8.Farmyard manure & $\mathrm{kg}$ & 0.3 & Shrestha DS. 1998. \\
\hline 9.Nylon & $\mathrm{kg}$ & 60 & Hetz EJ. 1998 \\
\hline 10. Seed & - & - & \\
\hline 11. Water for irrigation & $\mathrm{M}$ & 1.02 & Singh JM. 2002 \\
\hline Tomato & $\mathrm{unit}$ & 1.00 & GhasemiMobtaker H2010 2010 \\
\hline 12. Electricity & $\mathrm{kWh}$ & 11.93 & Singh JM. 2002 \\
\hline Tomato & $\mathrm{kg}$ & 1.00 & GhasemiMobtaker H 2010 \\
\hline 13. Output & - & - & \\
\hline Tomato & $\mathrm{kg}$ & 0.8 & Yaldiz O 1993 \\
\hline
\end{tabular}

Note:" The joule is the derived unit of energy in the International System of Units.

"The megajoule (MJ) is equal to one million $\left(10^{6}\right)$ joules, or approximately the kinetic energy of a one

Megagram (tons) vehicle moving at $161 \mathrm{~km} / \mathrm{h}$.

\section{Source: References in columns four}

The output-input energy ratio (energy use efficiency) is one of the indices that show the energy efficiency of agriculture. In particular, this ratio, which is calculated by the ratio of input fossil fuel energy and output food energy, has been used to express the ineffectiveness of crop production in developed countries (Unakitan G 2010). An increase in the ratio indicates improvement in energy efficiency, and vice versa. Changes in efficiency can be both short and long term, and will often reflect changes in technology, government policies, weather patterns, or farm management practices. By carefully evaluating the ratios, it is possible to determine trends in the 
energy efficiency of agricultural production, and to explain these trends by attributing each change to various occurrences within the industry (Unakitan G 2010).

The output-input energy ratio (energy use efficiency) is one of the indices that show the energy efficiency of agriculture. In particular, this ratio, which is calculated by the ratio of input fossil fuel energy and output food energy, has been used to express the ineffectiveness of crop production in developed countries (Unakitan $G$ 2010). An increase in the ratio indicates improvement in energy efficiency, and vice versa. Changes in efficiency can be both short and long term, and will often reflect changes in technology, government policies, weather patterns, or farm management practices. By carefully evaluating the ratios, it is possible to determine trends in the energy efficiency of agricultural production, and to explain these trends by attributing each change to various occurrences within the industry (Unakitan G 2010).

\section{Results And Discussion}

\section{Energy Use Pattern}

The components of the energy use pattern for cultivating traditional tomato are shown in (Table 2)76 kg nitrogen, $45 \mathrm{~kg}$ Phosphate, $96 \mathrm{~kg}$ potassium, 505L diesel fuel, $1880 \mathrm{~m} 3$ water, $71.6 \mathrm{~kg}$ chemical spraying agents, $1200 \mathrm{~h}$ human power, $25 \mathrm{~h}$ machinery, per fedden are used for the production of traditional tomato in Ismailia governorate

The average traditional tomato output were found to be $24000 \mathrm{~kg} / \mathrm{fed}$. The energy equivalent of this is calculated as $19200 \mathrm{MJ} / \mathrm{fed}$. Finally, the energy used in the production of traditional tomato consists of $18.7 \%$ chemicals, $5.2 \%$ human power, $3.5 \%$ machinery, $14.8 \%$ fertilizers, $53.6 \%$ fuel (diesel) and $4.3 \%$ water inputs. The highest energy input is provided by diesel fuel.

Table.2. the physical inputs used in the production of organic and traditional tomato and their energy equivalences.

\begin{tabular}{|c|c|c|c|c|c|c|}
\hline \multirow[t]{2}{*}{ Inputs } & \multicolumn{3}{|c|}{ Traditional tomato } & \multicolumn{3}{|c|}{ Organic tomato } \\
\hline & Amount & MJ & $\%$ & Amount & MJ & $\%$ \\
\hline 1-Biological control & - & - & & $50 \mathrm{~kg}$ & 7356 & 19.5 \\
\hline Herbicides & - & - & & - & - & \\
\hline Fungicides & - & - & & $20 \mathrm{~kg}$ & 4320 & \\
\hline Insecticides & - & - & & $30 \mathrm{~kg}$ & 3036 & \\
\hline 1-Chemicals & $71.6 \mathrm{~kg}$ & 8422.6 & 18.7 & - & & \\
\hline Herbicides & $6 \mathrm{~kg}$ & 1428 & & - & & \\
\hline Fungicides & $3.1 \mathrm{~kg}$ & 669.6 & & - & & \\
\hline Insecticides & $62.5 \mathrm{~kg}$ & 6325 & & & & \\
\hline 2.Human power & $1200 \mathrm{~h}$ & 2352 & 5.2 & $1056 \mathrm{~h}$ & 2069.8 & 5.5 \\
\hline 3-Machinery & $25 \mathrm{~h}$ & 1567.5 & 3.5 & $22 \mathrm{~h}$ & 1379.4 & 3.7 \\
\hline 4- Chemicals Fertilizer & $217 \mathrm{~kg}$ & 6656.8 & 14.8 & - & & \\
\hline Nitrogen fertilizer & $76 \mathrm{~kg}$ & 5026.6 & & - & & \\
\hline Phosphate $\mathrm{P}_{2} \mathrm{O}_{5}$ & $45 \mathrm{~kg}$ & 559.8 & & - & & \\
\hline Potassium $\mathrm{K}_{2} \mathrm{O}$ & $96 \mathrm{~kg}$ & 1070.4 & & - & & \\
\hline 5- compost & - & & & 12 ton & 3600 & 9.5 \\
\hline 6- Seeds & 0.150 & 0.150 & & $0.120 \mathrm{~kg}$ & 0.120 & \\
\hline 7. Diesel fuel & $505 \mathrm{~L}$ & 24139 & 53.6 & $455 \mathrm{~L}$ & 21749 & 57.6 \\
\hline 8-Water & $1880 \mathrm{~m} 3$ & 1917.6 & 4.3 & $1548 \mathrm{~m} 3$ & 1579 & 4.2 \\
\hline Total energy input & & 45056 & 100 & & 37733 & 100 \\
\hline Output & & & & & & \\
\hline Yield & $24000 \mathrm{~kg}$ & 19200 & & $22000 \mathrm{~kg}$ & 17600 & \\
\hline
\end{tabular}

Source: The survey carried out in Ismailia governorate 2017, and table 1 
The components of the energy use pattern for organic tomatoproduction are shown in (Table 2) compost 12 ton, $455 \mathrm{~L}$ diesel fuel, $1548 \mathrm{~m} 3$ water, $50 \mathrm{~kg}$ Biological control, $1056 \mathrm{~h}$ human power, $22 \mathrm{~h}$ machinery, per fedden are used for the production of organic tomato in Ismailia governorate.

The average organic tomato output were found to be $22000 \mathrm{~kg} / \mathrm{fed}$. The energy equivalent of this is calculated as $17600 \mathrm{MJ} /$ fed. Finally, the energy used in the production of organic tomato consists of $19.5 \%$ Biological control, $5.5 \%$ human power, $3.7 \%$ machinery, $9.5 \%$ fertilizers, $57.6 \%$ fuel (diesel) and $4.2 \%$ water inputs. The highest energy input is provided by diesel fuel.

\section{Energy Indices in organic and traditional tomato production}

The energy ratio (energy use efficiency), energy productivity, specific energy, net energy gain and the distribution of inputs used in the production of organic and traditional tomato according to the direct, indirect, renewable and non-renewable energy groups, are given in (Table 3 ).

Table.3. Energy output-input ratio and type of energy forms for organic and traditional tomato production.

\begin{tabular}{|c|c|c|c|c|c|}
\hline Items & Unit & $\begin{array}{c}\text { Traditional } \\
\text { tomato }\end{array}$ & $\mathbf{\%}$ & Organic tomato & \% \\
\hline $\begin{array}{c}\text { Energy ratio(energy use } \\
\text { efficiency) }\end{array}$ & - & 0.43 & & 0.47 & \\
\hline Energy productivity & $\mathrm{Kg} / \mathrm{MJ}$ & 0.53 & & 0.58 & \\
\hline Specific energy & $\mathrm{MJ} / \mathrm{kg}$ & 1.87 & & 1.72 & \\
\hline Net energy & $\mathrm{MJ} / \mathrm{fed}$ & -25856 & & -20133 & \\
\hline Direct energy a & $\mathrm{MJ} / \mathrm{fed}$ & 28409 & 63 & 25398 & 67 \\
\hline Indirect energy b & $\mathrm{MJ} / \mathrm{fed}$ & 16647 & 36 & 12335.5 & 33 \\
\hline Renewable energy c & $\mathrm{MJ} / \mathrm{fed}$ & 4269.7 & 9.5 & 7248.9 & 19 \\
\hline Non- renewable energy d & $\mathrm{MJ} / \mathrm{fed}$ & 40786 & 90.5 & 34084 & 90.3 \\
\hline Total energy input & $\mathrm{MJ} / \mathrm{fed}$ & 45056 & 100 & 37733 & 100 \\
\hline Energy output & $\mathrm{MJ} / \mathrm{fed}$ & 19200 & & 17600 & \\
\hline
\end{tabular}

Note: aIncludes human power, diesel, water;

b Includes chemical fertilizers, compost, chemicals,Biological control,seeds, machinery;

c Includes human power, compost, seeds, water;

d Includes diesel, Biological control,chemicals, chemical fertilizers,compost, machinery. Source: Table 2

The ratio of renewable energy including the energies of human power, seeds, compost and water inputs, within the total energy in all productions is very low (Fig. 1). Renewable energy resources (diesel, hydroelectric, biomass, wind, ocean and geothermal energy) are inexhaustible and offer many environmental benefits over conventional energy sources. Each type of renewable energy also has its own special advantages that make it uniquely suited to certain applications (Miguez JL 2006).

The use of renewable energy offers a range of exceptional benefits, including: a decrease in external energy dependence; a boost to local and regional component manufacturing industries; promotion of regional engineering and consultancy services specializing in the use of renewable energy, decrease in impact of electricity production and transformation; increase in the level of services for the rural 
population; creation of employment, etc. Within the enterprises that were analyzed, the share of non-renewable energy for organic and traditional tomato production was $90.3 \%, 90.5 \%$, respectively.

The energy ratio (energy use efficiency) in (Table 3) was calculated as 0.47 and 0.43 for organic tomato and traditional tomato production. The results of research indicated for The energy ratio (energy use efficiency) value of organic tomato in Ismailia governorate. The higher value of the energy ratio (energy use efficiency) for organic tomato production in this region can be explained by the efficiency of irrigation water and optimization of compost that affect in total energy consumption. The results of (Table 3) showed that the Energy use efficiency was low for traditional tomato production in Ismailia governorate. The reason of The energy ratio (energy use efficiency) in this research in comparison with other researches may be including: low yield, using high energy inputs consumption, etc. It is clear that the use of renewable energy in this region is very low, indicating that organic tomato and traditional tomato production depends mainly on oil fuels. By raising the crop yield, decreasing energy inputs consumption, use of renewable energy and optimization of energy consumption ratio can be increased.

Fig.1. Comparison between the share of energy forms for organic and traditional tomato productions

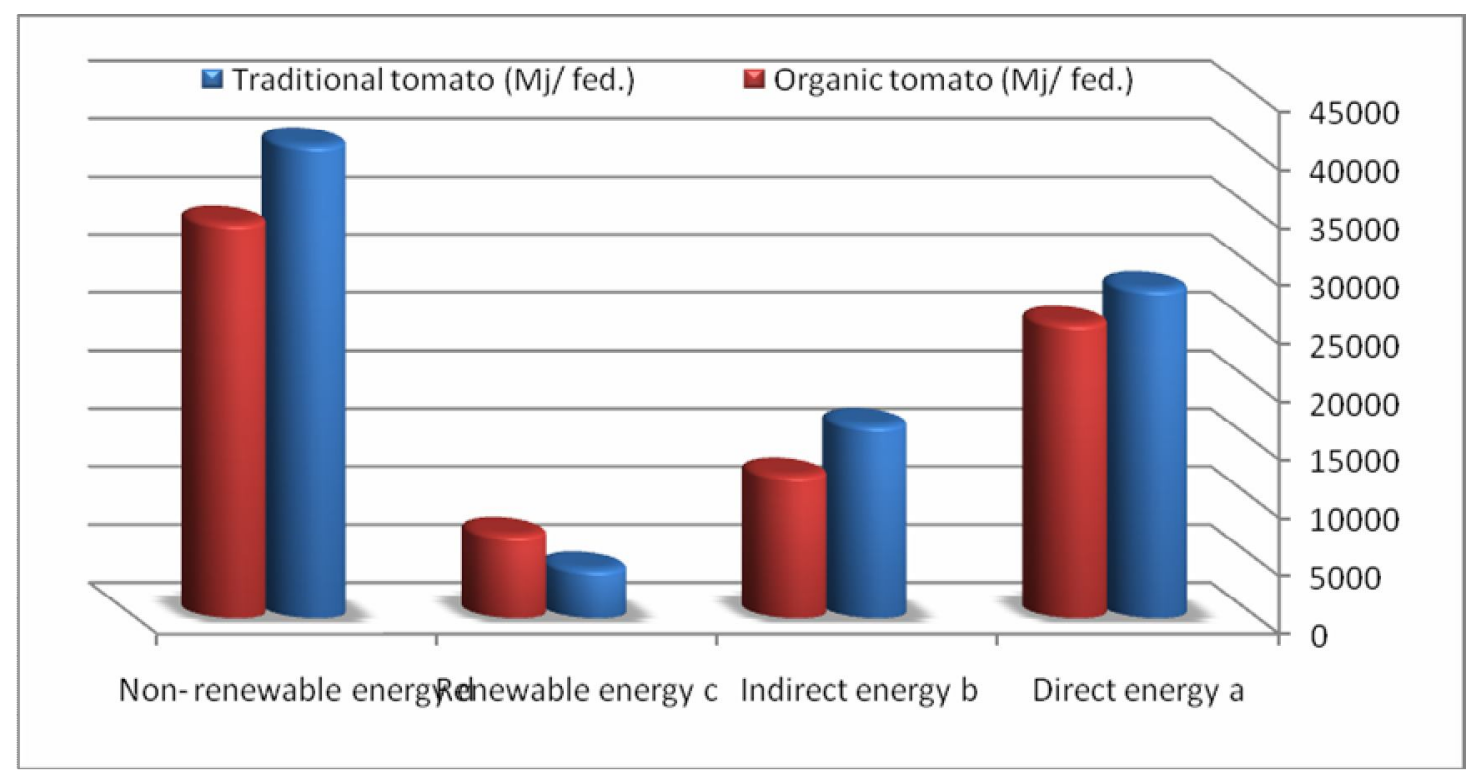

\section{Source: The survey carried out in Ismailia governorate 2017}

Energy productivity for organic and traditional tomato production was calculated by $0.58,0.53, \mathrm{MJ} / \mathrm{kg}$, respectively. The net energy of organic tomato and traditional tomato production was negative.

Studied energy efficiency, energy productivity, specific energy and net energy for organic tomato which amount of above indices were reported as $0.47,0.58 \mathrm{~kg} / \mathrm{MJ}$, $1.72 \mathrm{MJ} / \mathrm{kg}$ and-20133 MJ/fed., respectively.

\section{Greenhouse Gas Emission for Organic and Traditional tomato Productions}

Table (4) shows the $\mathrm{CO}_{2}$ emission for organic and traditional tomato Production in Ismailia governorate. Results of this table indicated that traditional 
tomato production is mostly depending on diesel fuel sources. Diesel fuel had the highest share (1393.8 $\left.\mathrm{kgCO}_{2} \mathrm{eq} / \mathrm{fed}\right)$ followed by Insecticides $\left(243.75 \mathrm{~kg} \mathrm{CO}_{2} \mathrm{eq} / \mathrm{fed}\right)$ and Machinery (111.2925 $\left.\mathrm{kg} \mathrm{CO}_{2} \mathrm{eq} / \mathrm{fed}\right)$. Also organic tomato production is mostly depending on diesel fuel sources. Diesel fuel had the highest share $(1255.8 \mathrm{~kg}$ $\mathrm{CO}_{2}$ eq/fed) followed by Insecticides $(117 \mathrm{~kg} \mathrm{CO}$ eq/fed) and Fungicides (102 kg $\mathrm{CO}_{2}$ eq/fed). As it can be seen in Table 4, the total Quantity of $\mathrm{CO}_{2}$ emission for traditional tomato is more than total Quantity of $\mathrm{CO}_{2}$ emission for organic tomato by $22.6 \%$. Using ethanol and biodiesel as biofuel is essential in the 21 st century to reduce the high GHG emissions. Field operations with minimum machinery use (especially tillage operation) and machinery production are needed to be considered to reduce the Quantity of $\mathrm{CO}_{2}$.

Table 4:Quantity of greenhouse gas emission for organic and traditional tomato

\begin{tabular}{|c|c|c|c|c|c|c|}
\hline Inputs & unit & $\begin{array}{c}\text { traditional } \\
\text { tomato } \\
\text { Quantity } \\
\text { per unit } \\
\text { area }\end{array}$ & $\begin{array}{l}\text { organic } \\
\text { tomato } \\
\text { Quantity } \\
\text { per unit } \\
\text { area }\end{array}$ & $\begin{array}{c}\text { GHG } \\
\text { Coefficient } \\
\underset{\text { unit) }}{\text { (kg } \mathrm{CO}_{2} \mathrm{eq} /} \\
\end{array}$ & $\begin{array}{c}\text { traditional } \\
\text { tomato } \\
\text { Quantity of } \\
\text { GHG } \\
\text { emission } \\
\text { (kg CO C2eq/ } \\
\text { fed) }\end{array}$ & $\begin{array}{c}\text { organic } \\
\text { tomato } \\
\text { Quantity of } \\
\text { GHG } \\
\text { emission } \\
\text { (kg CO} \mathbf{C O}_{2} \text { eq/ } \\
\text { fed) }\end{array}$ \\
\hline Machinery & $\mathrm{MJ} / \mathrm{fed}$ & 1567.5 & 1379.4 & 0.071 & 111.2925 & 97.9374 \\
\hline Diesel fuel & $\mathrm{L} / \mathrm{fed}$ & 505 & 455 & 2.76 & 1393.8 & 1255.8 \\
\hline $\begin{array}{l}\text { Chemicals } \\
\text { Fertilizer }\end{array}$ & 21 & - & - & - & & . \\
\hline Nitrogen & $\mathrm{Kg} / \mathrm{fed}$ & 76 & - & 1.3 & 98.8 & - \\
\hline Phosphate $\mathrm{P}_{2} \mathrm{O}_{5}$ & $\mathrm{Kg} / \mathrm{fed}$ & 45 & - & 0.2 & 9 & - \\
\hline Potassium $\mathrm{K}_{2} \mathrm{O}$ & $\mathrm{Kg} / \mathrm{fed}$ & 96 & - & 0.2 & 19.2 & - \\
\hline $\begin{array}{c}\text { 1-Biological } \\
\text { control }\end{array}$ & $\mathrm{Kg} / \mathrm{fed}$ & - & - & - & - & - \\
\hline Herbicides & $\mathrm{Kg} / \mathrm{fed}$ & - & - & 6.3 & - & - \\
\hline Fungicides & $\mathrm{Kg} / \mathrm{fed}$ & - & 20 & 5.1 & - & 102 \\
\hline Insecticides & $\mathrm{Kg} / \mathrm{fed}$ & - & 30 & 3.9 & - & 117 \\
\hline $\begin{array}{l}\text { 2-Chemical } \\
\text { control }\end{array}$ & $\mathrm{Kg} / \mathrm{fed}$ & - & - & - & - & - \\
\hline Herbicides & $\mathrm{Kg} / \mathrm{fed}$ & 6 & - & 6.3 & 37.8 & - \\
\hline Fungicides & $\mathrm{Kg} / \mathrm{fed}$ & 3.1 & - & 5.1 & 15.81 & - \\
\hline Insecticides & $\mathrm{Kg} / \mathrm{fed}$ & 62.5 & - & 3.9 & 243.75 & - \\
\hline Total $\mathrm{CO}_{2}$ & & & & & 1929.4525 & 1572.7374 \\
\hline
\end{tabular}

Source: Table 2

\section{Economic Indicators of Organic and Traditional tomato production}

The total cost of production, gross income, net income and benefit-cost ratio (B/C ratio) were calculated and are given in (Table 5). Machinery with 8400 (L.E/fed) was the most cost in organic tomato production and followed by Opportunity cost of land with $6500(\mathrm{~L} . \mathrm{E} / \mathrm{fed})$. The total cost for the production was 32970(L.E/fed) while the gross income was found to be 8800 (L.E/fed). The net income and benefit-cost ratio (B/C)calculated55030 (L.E/fed) and1.7 respectively.

Because the government of Egypt doesn't give support to organic farms. Also show (Table 5) Machinery with 7200 (L.E/fed) was the higher cost in Traditional tomato production and followed by Opportunity cost of landwith $5000(\mathrm{~L} . \mathrm{E} / \mathrm{fed})$. The total cost for the production was 28200 (L.E/fed) while the gross income was found 
to be $60000(\mathrm{~L} . \mathrm{E} / \mathrm{fed})$.The net income and benefit-cost ratio calculated 31800 (L.E/fed) and 1.1 respectively.

Table 5:Estimated Economic Indicators of organic and traditional tomato production

\begin{tabular}{|l|c|c|}
\hline \multicolumn{1}{|c|}{ Cost } & $\begin{array}{c}\text { Traditional tomato } \\
\text { Value (L.E/fed) }\end{array}$ & $\begin{array}{c}\text { Organic tomato } \\
\text { Value (L.E/fed) }\end{array}$ \\
\hline Labour cost & 4870 & 5920 \\
\hline Opportunity cost of land & 5000 & 6500 \\
\hline Machinery cost & 7200 & 8400 \\
\hline Seed cost & 4800 & 6000 \\
\hline Pesticide cost & 2130 & 2550 \\
\hline Fertilizer cost & 4200 & 3600 \\
\hline Total cost & 28200 & 32970 \\
\hline Productivity & 24 ton & 22 ton \\
\hline Price & $2500(\mathrm{L.E} / \mathrm{ton})$ & 4000 (L.E/ton) \\
\hline gross income & 60000 & 88000 \\
\hline Net income (Benefit) & 31800 & 55030 \\
\hline Benefit - cost ratio (B/C) & $1.1 \%$ & $1.7 \%$ \\
\hline Source: The survey carried
\end{tabular}

Source: The survey carried out in Ismailia governorate 2017

\section{Carbon trade}

\section{Carbon trade in Egypt:}

Egypt signed the Kyoto Protocol on 15 March 1999, March and ratified as of 12 January (January) 2005. Egypt's efforts have gone into reducing greenhouse gas emissions and that the rationalization of consumption, and reduce leakage of transmission networks and distribution of oil and gas, and solid waste treatment with the use of treated wastewater. It is known that total greenhouse gas emissions in Egypt reached $2.6 \mathrm{M}^{\text {.tonCO }} \mathrm{C}_{2}, 22 \%$ of the energy sector, $21 \%$ of industry, and $15 \%$ of the agricultural sector, and $18 \%$ of the transport sector, and $9 \%$ of small industries, and $9 \%$ of traditional industries and $6 \%$ of Residuals.

- The main objectives of the carbon market are to reduce costs associated with emission reductions.

- Reducing emission would be economically feasible if the price of 20 to $30 \$ /$ ton.

- Both the public and private sectors should be involved in reducing $\mathrm{CO}_{2}$ emissions. Promotes a shift towards low-carbon technology and information exchange, and promotes inter-linkages between different sciences.

- According to the IPCC report, the sale price of carbon tones should be $50 \$$ in 2020 to increase investment in advanced technology industries that reduce carbon footprint.

- According to the study, the production of organic tomato reduces emissions by $18 \%$ than traditional tomato equivalent78.6 \$/fedThe area of tomatoes in Egypt in 2015 is about $187135 \mathrm{Fed}($ Economic Affairs Sector)if converted to organic agriculture provide around 14.7 million \$/year.

\section{Conclusions}

\section{Based on the present study the following conclusions are drawn}

1) Greenhouse organic tomato production consumed a total energy of $37733 \mathrm{MJ} / \mathrm{fed}$, which was mainly due to diesel fuel (57.6\% of total energy). The input energy of total Biological control and compost have the secondary and tertiary share within the total energy inputs. Energy output was calculated as $17600 \mathrm{MJ} / \mathrm{fed}$. Also 
Greenhouse organic tomato production consumed a total energy of $45056 \mathrm{MJ} / \mathrm{fed}$, which was mainly due to diesel fuel (53.6\% of total energy). The input energy of total chemical and chemicals fertilizer have the secondary and tertiary share within the total energy inputs. Energy output was calculated as $19200 \mathrm{MJ} / \mathrm{fed}$

2) The direct and indirect input energies were $67 \%$ and $33 \%$ of the total input energy, for organic tomato production respectively. Renewable energy sources among the inputs had a share of $19 \%$ of the total energy input, which was smaller than that of non-renewable resources. As well The direct and indirect input energies were $63 \%$ and $36 \%$ of the total input energy, for organic tomato production respectively. Renewable energy sources among the inputs had a share of $9.5 \%$ of the total energy input, which was smaller than that of non-renewable resources.

3) Total amount of $\mathrm{CO}_{2}$ emission in organic tomato production was calculated as $1572.7374 \mathrm{~kg} \mathrm{CO} \mathrm{Cq}_{2} \mathrm{fed}$. Diesel fuel had the highest share (57.6 \%), Total amount of $\mathrm{CO}_{2}$ emission in organic tomato production was calculated as $1929.4525 \mathrm{~kg}$ $\mathrm{CO}_{2} \mathrm{eq} / \mathrm{fed}$. Diesel fuel had the highest share (53.6\%). It is possible to decrease greenhouse gas emission in agricultural production by reduction of nonrenewable energy sources that create environmental problems. Therefore, policy makers should take the necessary measurements to ensure more environmental friendly energy use patterns in the Egyptian agriculture.

4) Reducing diesel fuel consumption and fertilizer usage, mainly nitrogen, is important for energy reduction. A saving in diesel fuel by improving tillage and hitting performance may be possible. Using direct and local marketing improves profitability for growers while reducing the amount of energy used to transport products.

5) The benefit-cost ratio $(\mathrm{B} / \mathrm{C})$ was found to be 1.7 for organic tomato, while the benefit- cost ratio $(\mathrm{B} / \mathrm{C})$ was found to be 1.1 for Traditional tomato, and thus invest in organic farming is the best in terms of profit.

\section{Summary :}

The aim of this study is to examine the energy use patterns and energy inputoutput analysisof organic and traditional tomato production. For this purpose, the survey was carried in 2017 by interviewing 30 Farmers in Ismailia governorate. Results indicated that a total input energy of 37733 and $45056 \mathrm{MJ} /$ fed was consumed for organic tomato and traditional production respectively. Diesel fuel (with 57.6\%, $53.6 \%$ ) and biological control, chemical (with 19.5\%, 18.7\%) were amongst the highest input energies for organic and traditional tomato production. The energy productivity was estimated to be $0.58 \mathrm{~kg} / \mathrm{MJ}, 0.53 \mathrm{~kg} / \mathrm{MJ}$. The ratio of output energy to input energy was approximately $0.47,0.43$ for organic and traditional tomato production respectively. Cost analysis revealed that total cost of production for fedden organic and traditional tomato production was around 32970, 28200 L.E /fed. Accordingly, the benefit-cost ratio (B/C) was estimated as 1.7, 1.1respectively. Results of greenhouse gas emission indicated that tomato production is mostly depended on diesel fuel sources. Diesel fuel had the highest share $\left(1255.8 \mathrm{kgCO}_{2} \mathrm{eq}\right.$. $/$ fed, $1393.8 \mathrm{kgCO}_{2}$ eq./fed)for organic and traditional tomato production respectively.

Keywords: Tomato, organic, energy productivity, economic Indicators. 


\section{References:}

- Alluvione, F., B. Moretti, D. Sacco and C. Grignani.( 2011). EUE (energy use efficiency) of cropping systems for a

- Canakci M, Topakci M, Akinci Iand Ozmerzi A. (2005).Energy use pattern of some field crops and vegetable production: Case study for Antalya Region, Turkey. Energy Conversion and Management. 39: 655-666.

- De D, Singh S, Chandra H. (2001). Technological impact energy consumption in rain fed soybean cultivation in Madhya Pradesh. Applied Energy. 70:193-213.

- Dyer, J.A. and R.L. Desjardins.( 2006). Carbon dioxide emissions associated with the manufacturing of tractors and farm machinery in Canada. Biosystems Engineering, 93(1): 107-118.

- Economic Affairs Sector, Agriculture Directorates of Governorates.The Agricultural Statistics.

- Ghasemi Mobtaker, H., Keyhani A., Mohammadi, A., Rafiee, Sh., Akram, A.,2010. Sensitivity analysis of energy inputs for barley production in Hamedan Province of Iran. Agriculture, Ecosystems \& Environment. 137(3-4): 367-72.

- Hetz EJ. 1998. Energy utilization in fruit production in Chile. AgrMech Asia Africa Latin Am (AMA).298(2):17- 20.

- Kizilaslan.H., (2009), "Input-output energy analysis of cherries production in Tokat Province of Turkey", Applied Energy, 86, pp 1354-1358.

- Miguez JL, Lopez-Gonzalez LM, Sala JM, PorteiroJ,Granada E, Moran JC. (2006). Review of compliance with EU-2010 targets on renewable energy in Galicia (Spain). Renew. Sustain. Energy Rev. 10: 225-247.

- Mohammadi A, Omid M. (2010). Economical analysis and relation between energy inputs and yield of greenhouse cucumber production in Iran.Applied Energy. 87(1): 191-6.

- Park, J. and RAF.Seaton.(1996). Integrative research and sustainable agriculture. Agricultural Systems, 50(1): 81-100.

- Sartori. L., Basso. B., Bertocco. M., and Oliviero. G., (2005), "Energy use and economic evaluation of a three year crop rotation for conservation and organic farming in NE Italy", Biosystems Engineering, 9 (2), pp 245-250

- Shrestha DS.(1998). Energy use efficiency indicator for agriculture. See also http://www.usaskca/agriculture/ caedac/PDF/mcrae.PDF, 10/10/2002.

- Singh JM.(2002). On farm energy use pattern in different cropping systems in Haryana, India. Master of Science, International Institute of Management University of Flensburg, Germany

- Singh. H., Mishra. D. and Nahar. N.M.,(2002), " Energy use pattern in production agriculture of typical village in arid zone", India-part-I. Energy Convers Manage, 43:2275-86. 
- Streimikiene. D., Klevas. V., and Bubeliene. J., (2007), "Use of EU structural funds for sustainable energy development in new EU member states", Renew Sustain Energy Rev, 116, pp 1167-87

- sustainable agriculture. Energy, 36(7): 4468-4481

- Tol, R.S.J., S.W. Pacala and R.H. Socolow.( 2009). Understanding long-term energy use and carbon dioxide emissions in the USA.J Pol Model, 31(3): 425-445.

- Unakitan G, Hurma H, Yilmaz F. (2010). An analysis of energy use efficiency of canola production in Turkey. Energy. 35: 3623-3627

- Yaldiz O, Ozturk HH, Zeren Y, Bascetincelik A. (1993). Energy use in 7eld crops of Turkey. 5. International Congress of Agricultural Machinery and Energy. Kusadasi, Turkey, (in Turkish).

\section{الآثار الاقتصادية للزر اعة العضوية في الحد من انبعاثات غازات الاحتباس الحرارى د/ المالد السبد عبد المولى محمد$$
\text { باحث أول - المعمل المركزي للزراعة العضوية- مركز البحوث الزراعية }
$$

الملخص

تعد الزر اعة العضوية كنهج بديل لتعظيم أداء المو ارد المتجددة وزيادة تذفق الغذاء و الطاقة في النظم الزراعية البيئية. وتظهر تقييمات دورة الحياة أن الانبعاثات الناتجة عن نظم الانتاج التقليدية دائماً ما تكون أعلى من انبعانات النظم العضوية، و السؤال هل تقلل الزر اعة العضوية انبعاثات غاز ات الاحتباس الحرارى من الانتاج الزراعى. وما هو العائد من التوسع فى المساحات المزروعة بنظم الزر اعة العضوية.

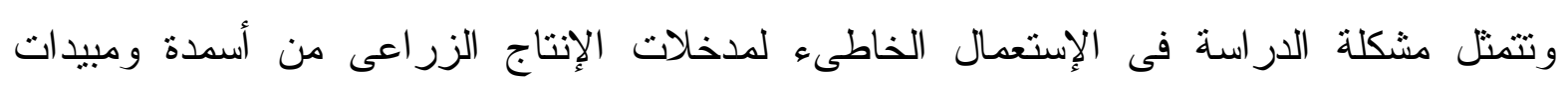
كيماوية مما يؤدى إلى زيادة الإنبعاثات من غاز ات الإحتباس الحر ارى. يهدف البحث إلى توضيح أهمية الزراعة العضوية فى تخفيف أثنار غاز ات الإنيكات الاحتباس الحرارى من خلال دراسة مقارنة لمحصول الطماطم تحت نظم الزر اعة العضوية و التقليدية فى مصر ، وكذلك دراسة

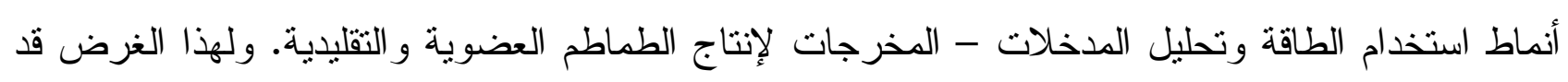

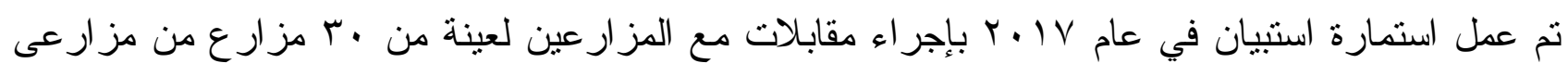
الطماطم العضوية و النقليدية في محافظة الإسماعيلية و التى تعتبر من المحافظات التى تتنتر بها الطماطم

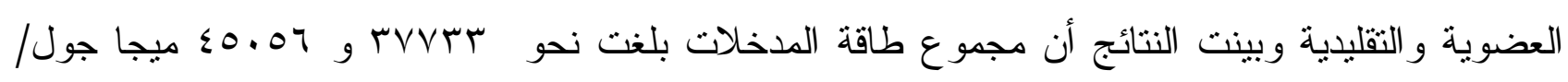

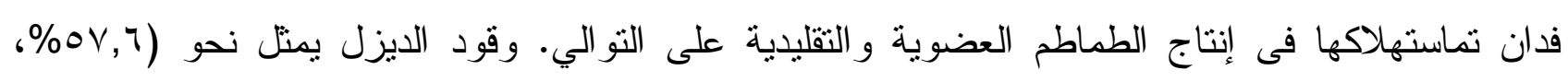




\section{in Reducing the Emission Greenhouse Gases}

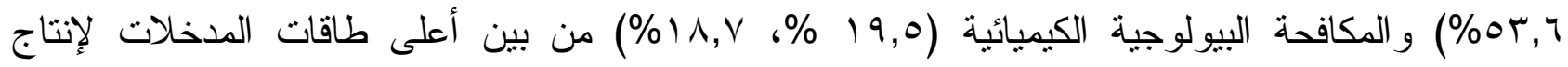
الطماطم العضوية و التقليدية وقدرت إنتاجية الطاقة لتكون O1, • كجم/ ميجا جول، rه, • كجم/ميجا جول.

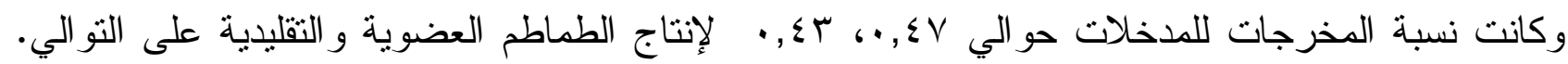
وتبين من دراسة التكاليف الإنتاجية أن التكلفة الإجمالية لإنتاج الطماطم العضوية و النقليدية بلغت حوالي

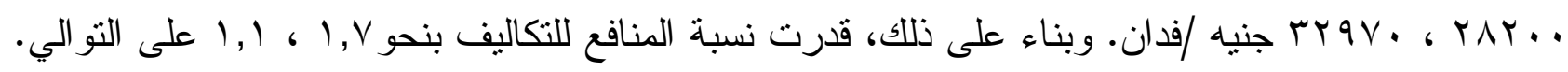
وأثنارت نتائج انبعاثات غازات الاحتباس الحراري إلى أن إنتاج الطماطم كلا النوعين يعتمد معظمها على مصادر وقود الديزل. كان أعلى حصة من وقود الديزل (1) (1) كجم /فدان) للطماطم العضوية و التقليدية على التو الي. وتوصى الدراسة بضرورة التحول إلى الزراعة العضوية، و الإعتماد على مصادر الطاقة النظيفة مثل الطاقة الثمسية وطاقة الرياح و المياه للحد من إنبعاثات غاز ات الإحتباس الحر اى. 